\title{
Analysis of the impact of a flexible photovoltaic tile shape on its performance
}

\author{
Dariusz Kurz ${ }^{1, *}$, Lena Morawska $^{1}$, Robert Piechota $^{1}$, and Grzegorz Trzmiel ${ }^{1}$ \\ ${ }^{1}$ Poznan University of Technology, Faculty of Electrical Engineering, Institute of Electrical \\ Engineering and Electronics, St. Piotrowo 3a, 60-965 Poznan, Poland
}

\begin{abstract}
This paper addresses the subject of the building integrated photovoltaics (BIPV). The flexible thin-film CIGS module has been subjected to testing in order to investigate its electrical parameters and the possibilities of adaptation to the building structure. During analysis of performance of the tested building in real conditions, particular attention has been paid to changes in its parameters depending on the inclination angle and the shape of its surface in relation to the incident solar radiation. Current-voltage characteristics and power curves in the selected configuration of module deflections have been analysed. Changing the module's inclination angle from the optimal $40^{\circ}$ to $0^{\circ}$ (horizontal arrangement of the module on the ground) reduced the value of generated current (by approx. 26\%), voltage increase (by approx. 4\%) and output power reduction by approx. $25 \%$. The module generated a lower power compared to the basic test due to the irradiation limit reaching its surface (decrease in the irradiance value of less than $60 \%$ from 800 to $330 \mathrm{~W} / \mathrm{m}^{2}$ ). Bending the module at an angle $90^{\circ}$ to the ground affected the large unevenness of solar radiation values reaching its surface and even greater losses of generated energy. The values of idle voltage, short-circuit current and voltage in MPP did not change much in relation to the base measurement, however, a large drop in the value of current in MPP was noted, which led to a significant reduction of output power. Thus, the need to strive for the most advantageous exposure of BIPV elements in relation to the sun was demonstrated and the losses on energy yields resulting from the integration of photovoltaic tiles into the body of the building have been estimated.
\end{abstract}

\section{Introduction}

Photovoltaic systems are present in many forms. In applications with building installations, the following systems can be distinguished: BIPV (Building Integrated Photovoltaics) integrated with the building and BAPV (Building Applied Photovoltaics) installed on the building surface. At present, the most frequently applied systems are the BAPV systems which do not fulfil any additional function except electricity production. In addition, free-standing systems are installed in ground-mounted installations (PV farms)

\footnotetext{
* Corresponding author: dariusz.kurz@put.poznan.pl
} 
and systems on one-axis and two-axis tracking system that change their orientation and inclination angle toward the Sun $[1,2]$.

Attempts at obtaining the best possible results in terms of the gained energy and the accomplishment of the maximum economic profits caused the development of the concept of photovoltaics integration into the building structure. The concept assumes the application of photovoltaic modules mainly as an alternative for traditional building elements within roofs and facades [3].

Because of, among other things, the high price and lack of standardisation of sizes, the BIPV system is not commonly used yet and its share in the photovoltaic market constitutes hardly about $1 \%[1,2]$. Furthermore, BIPV elements are not installed on solar tracking systems to improve the effectiveness of energy generation [4, 5]. The installation of photovoltaic tiles in the building roof also limits the natural cooling of PV cells, which results in a higher temperature of cells and a decrease in the value of the obtained voltages, and consequently also a decrease in the efficiency and power yield [6-9]. The uneven lighting of PV cells complicates the implementation of the mathematical model and simulation calculations aimed at determining the real energy yield, which makes it necessary to use advanced methods and computational tools [10-12]. The quantitative determination of the value of generated power is an important parameter necessary in calculating the energy storage capacity in autonomous systems or emergency supply of various facilities or vehicles [13-16]. However, the BIPV market, priced by the " $n$-tech Research" organization in 2015 at about 3000 million dollars, should reach the value of 7000 million dollars in 2018, while by 2022 it will exceed the value of 26000 million dollars. On the other hand, it is estimated that alone photovoltaic roofing will reach 0.65 million dollars in 2018, 1.3 million dollars in 2022 and up to 2.7 million dollars in 2026 $[17,18]$.

One the most frequently used solutions is the integration of photovoltaics with a building using photovoltaic tiles [19]. As integral components of the building envelope, they generate electricity, being characterised at the same time with all the waterproofing properties of ordinary roof tiles. Roof covers which maintain the shape of traditional ceramic tiles and consist of several serially connected cells - bituminous tiles - are manufactured.

The characteristic feature of the applied second-generation (thin-film) photovoltaic modules is very low thickness of the light-absorbing semi-conductor layer [20]. The state of-the-art technologies allow to achieve the flexibility of modules which can be installed in many different ways $[7,8,21]$. Therefore, a decision has been taken to investigate the impact of shaping the selected thin-film CIGS module on the electric energy yield. A single roof tile was positioned in three different variants, which allowed to obtain a different distribution of intensity of solar radiation incident on its surface. The research that was carried out aimed at analyzing the possibility of using the chosen CIGS module on roofs of various shapes (e.g. on round, oval elements, or installing PV tiles on two neighboring building walls connected at different angles) and estimation of energy yield generated during its uneven lighting.

\section{Test method}

\subsection{Subject of testing}

A flexible photovoltaic module - CIGS FLEX-01 70N manufactured by MiaSolé, with the maximum output of $70 \mathrm{~W}$ was used for the testing purposes. The thin-film solar cell based on the CIGS technology is enclosed in a polymer cover. Solar cells are provided with 
a bypass diode soldered in parallel, which enables the flow of current, if any part of the module is shaded.

The role of the conductive material in this module is fulfilled by the mixture of copper, indium, gallium and selenium. Owing to the use of these four elements, the cell can absorb more sunlight - direct, reflected as well as dispersed one. Thus, it is characterised by an exceptional efficiency in poor lighting conditions. The effectiveness of the CIGS modules is relatively moderate and may reach 15-20\% [22-25]. An unquestionable advantage of the tested PV modules is also the possibility of installation by means of self-adhesive glue which is peelable for the majority of surfaces. Thus, no additional supporting structure is necessary [26].

Table 1. presents the most important parameters of the tested PV roof tile, which were determined in standard test conditions (STC), i.e.: irradiance - $1000 \mathrm{~W} / \mathrm{m}^{2}$, module's operating temperature $-25^{\circ} \mathrm{C}$ and air mass equal to 1.5 .

Table 1. Parameters of the CIGS FLEX-01 70N module manufactured by MiaSolé [26].

\begin{tabular}{|l|l|}
\hline \multicolumn{1}{|c|}{ Parameter } & \multicolumn{1}{c|}{ Value } \\
\hline Dimensions & $(1710 \times 370 \times 17) \mathrm{mm}$ \\
\hline Active surface & $0.6327 \mathrm{~m}^{2}$ \\
\hline Weight incl. adhesive substrate & $2.69 \mathrm{~kg}$ \\
\hline Nominal power & $70 \mathrm{~W}$ \\
\hline Power tolerance & $5 \mathrm{~W}$ \\
\hline Open circuit voltage & $27.9 \mathrm{~V}$ \\
\hline Short-circuit current & $3.70 \mathrm{~A}$ \\
\hline Voltage at MPP & $22.3 \mathrm{~V}$ \\
\hline Current at MPP & $3.25 \mathrm{~A}$ \\
\hline Efficiency & $11 \%$ \\
\hline Temperature coefficient of power & $-0.45 \% /{ }^{\circ} \mathrm{C}$ \\
\hline
\end{tabular}

\subsection{Measuring station}

Testing was performed on 19 October 2017 at about 2 p.m., in the climatic environment of the city of Poznan, on the premises of Poznan University of Technology $\left(52^{\circ} 23^{\prime} \mathrm{N}\right.$ $\left.16^{\circ} 55^{\prime} \mathrm{E}\right)$. The following weather conditions prevailed: ambient temperature $18^{\circ} \mathrm{C}$, wind speed $6 \mathrm{~km} / \mathrm{h}$ north-east (NE), air humidity $80 \%$, clear sky. The scope of the testing referred to the formulation of current-voltage characteristics and power-voltage characteristics of a photovoltaic module. The area of the measuring station was not encumbered by any elements which could cause partial shading of the module during analysis of performance.

The measuring circuit, allowing to determine the electric parameters and the value of the irradiance, consisted of the CIGS MiaSole FLEX-01 70N photovoltaic module, the slide resistor, the digital voltmeter, the digital ammeter, the pyranometer and the test leads.

The scope of the testing included analysis of three cases of system performance for different positions of the object in relation to the ground (or horizontal roof surface) and the bend angle of $0^{\circ}$ or $90^{\circ}$ (Fig. 1 and Fig. 2). The electrical parameters which allowed for the determination of the current-voltage characteristics and the power-voltage characteristics as 
well as operating parameters included in table 2 were measured. At the current stage of the research, the PV module was bent in the middle of its length to check the effect of different irradiance of each of the two equal module parts. At the further stage of the work, it is planned to analyze the change of the bending point to the obtained measurement values and the determined characteristics. In addition, an analysis of the serial and parallel connection of the bent and unbent module to the obtained parameters will be made. Also planned is the continuous work of the system (on different days and in different seasons) and the impact of module temperature changes on its electrical parameters.

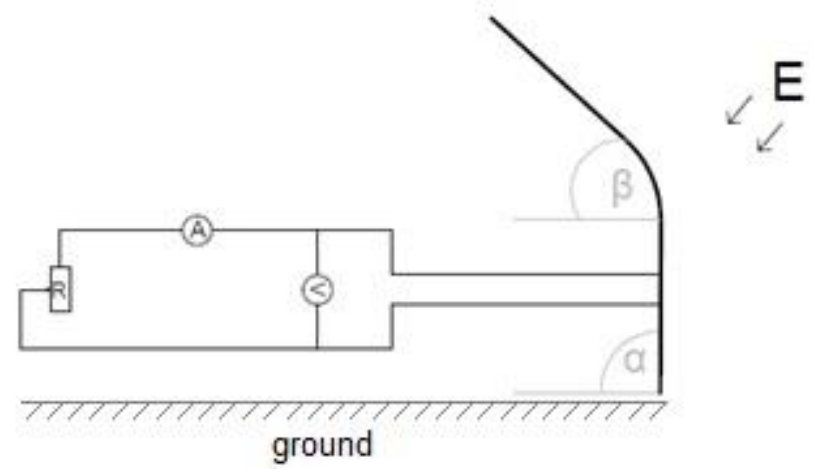

Fig. 1. Scheme of a testing station for a flexible PV roof tile:

$\mathrm{E}$ - irradiance $\left[\mathrm{W} / \mathrm{m}^{2}\right], \alpha$ - inclination angle of the module relative to the ground, $\beta-$ bend angle of the module relative to the ground.

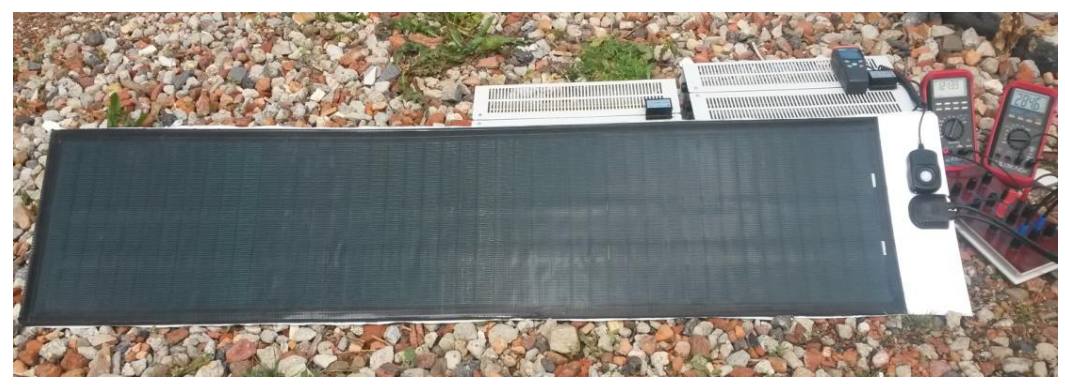

Fig. 2. View of a testing station for a flexible PV roof tile.

\section{Measurement results}

\subsection{Testing of the flexible PV roof tile}

The electricity yield of the PV module depends, above all, on the angle of its inclination as well as the surface temperature and the irradiance. A change in the bend angle causes an increase in the differences in intensity of radiation that reaches the respective parts of the module. The consequence is the change in the average of irradiance intensity and the obtained power. At the current stage of research, three selected variants of the module's positions were focused, the most optimal for Poland's climatic conditions (angle of the module relative to the ground about $40^{\circ}$ ), and also the most popular of single-family houses roofs angle too, and the module arrangement on the flat roof or building façade wall 
(inclination angles $0^{\circ}$ and $90^{\circ}$ ). The module was also bent at an angle of $90^{\circ}$ in the middle of its length in order to simulate laying it on two walls or wall and roof of the building.

The tested PV roof tile was positioned horizontally (parallel to the ground) at an angle of $\alpha=40^{\circ}$ to the ground surface without bending $\left(\beta=90^{\circ}\right)$. Due to the lack of unevenness of the surface, the solar radiation fell on the whole roof tile evenly. Fig. 3 presents the current-voltage characteristic for the analysed situation. Its shape approximates that of the theoretical graphs given in the literature, while the fill factor is $(\mathrm{FF})=0.68$. At the average of irradiance $(E)=798.25 \mathrm{~W} / \mathrm{m}^{2}$, the power with the value of $41.30 \mathrm{~W}$ was obtained, i.e. about $60 \%$ of the rated power and the efficiency equal to $8.18 \%$.

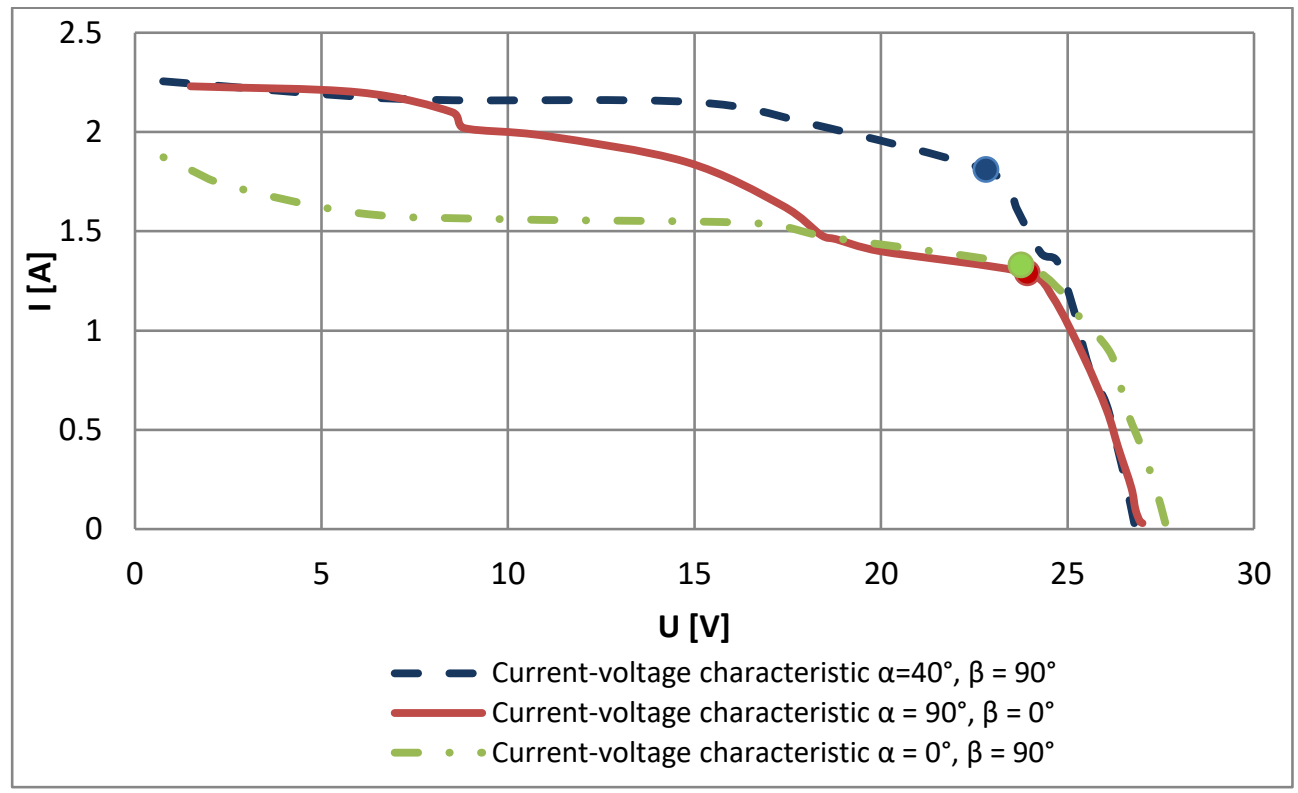

Fig. 3. Current-voltage characteristics for different PV module setting angles.

A reduction in inclination angle of the roof tile to $\alpha=0^{\circ}$ in relation to the surface of the ground caused a slight dispersion and reflection of the incident solar radiation, which is visible in the figure (Fig. 3.) in the form of a slight offset on the current-voltage characteristic (I-U). The obtained power was reduced to the value equal to $31.60 \mathrm{~W}$ because of a significant reduction in the value of the flowing current. With the irradiance reduction to $330 \mathrm{~W} / \mathrm{m}^{2}$ (by $60 \%$ ), power reduction by about $25 \%$ (Fig. 4.) was observed. However, this resulted in increased efficiency up to $\eta=15.14 \%$. The analysed PV roof tile works well at low inclination angles in relation to the ground surface. A change in the module position also caused the shift of the Maximum Power Point towards the open circuit voltage.

The positioning of the roof tile at an angle $\alpha=90^{\circ}$ to the ground surface and a decrease in bend angle $\beta=0^{\circ}$ resulted in the solar radiation falling on its surface with different intensity. In this situation, the bypass diodes integrated in the module allowed for the disconnection of the shaded solar cells and the flow of the current from the properly operating cells. The effects of diodes activation can be noticed in the presented currentvoltage characteristic and the power curve in the form of offsets (Fig. 3 and Fig. 4). Because of the high average of irradiance, the power yield, despite the shading of a certain 
part of the module, amounted to $30.87 \mathrm{~W}$. Thus, the maximum power fell by about $25 \%$ in relation to the optimally inclined and unbent roof tile $\left(\alpha=40^{\circ}, \beta=90^{\circ}\right)$.

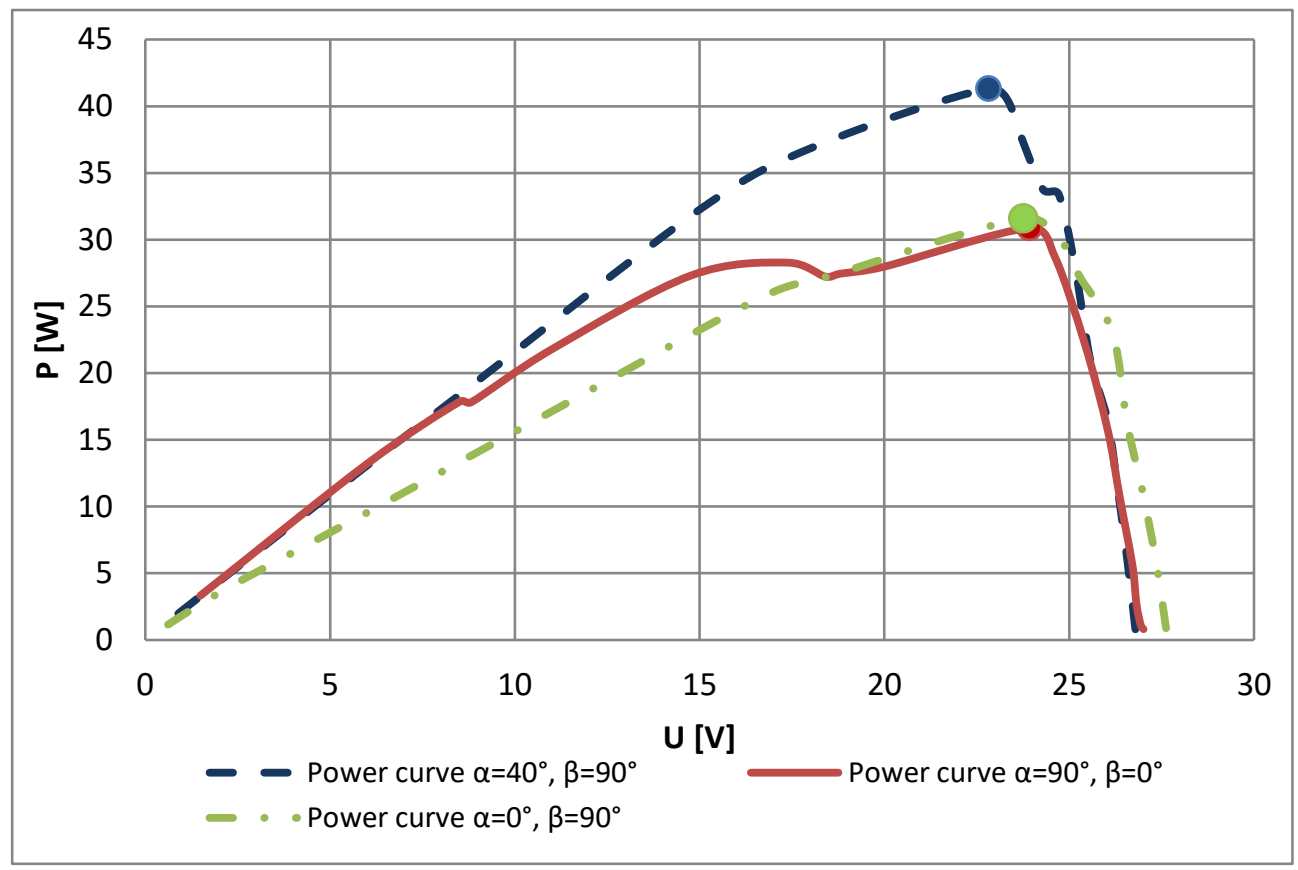

Fig. 4. Power-voltage characteristics for different PV module angles.

Table 2 compiles the data specification of the tested roof tile and the obtained measurement results in different position variants.

Table 2. Compilation of the test results for a single PV roof tile.

\begin{tabular}{|c|c|c|c|c|}
\hline \multirow[b]{2}{*}{ Parameter } & \multirow{2}{*}{$\begin{array}{l}\text { Manufacturer's } \\
\text { data (in STC) }\end{array}$} & \multicolumn{3}{|c|}{ Roof tile position } \\
\hline & & $\begin{array}{l}\alpha=40^{\circ} \\
\beta=90^{\circ}\end{array}$ & $\begin{aligned} \alpha=0^{\circ} \\
\beta=90^{\circ}\end{aligned}$ & $\begin{aligned} \alpha & =90^{\circ} \\
\beta & =0^{\circ}\end{aligned}$ \\
\hline $\begin{array}{l}\text { Open circuit voltage } \\
U_{o c}[V]\end{array}$ & 27.90 & 26.79 & 27.62 & 27.62 \\
\hline $\begin{array}{l}\text { Short-circuit current } \\
\mathrm{I}_{\mathrm{sc}}[\mathrm{A}]\end{array}$ & 3.70 & 2.26 & 1.9 & 2.23 \\
\hline $\begin{array}{l}\text { Voltage at Maximum Power Point } \\
\qquad U_{\mathrm{mpp}}[\mathrm{V}]\end{array}$ & 22.30 & 22.82 & 23.76 & 23.93 \\
\hline $\begin{array}{l}\text { Current at Maximum Power Point } \\
\mathrm{I}_{\mathrm{mpp}}[\mathrm{A}]\end{array}$ & 3.25 & 1.81 & 1.33 & 1.29 \\
\hline $\begin{array}{c}\text { Maximum power } \\
\mathrm{P}_{\max }[\mathrm{W}] \\
\end{array}$ & 70.00 & 41.30 & 31.60 & 30.87 \\
\hline $\begin{array}{l}\text { Fill Factor } \\
\text { FF[-] }\end{array}$ & 0.68 & 0.68 & 0.60 & 0.51 \\
\hline $\begin{array}{c}\text { Efficiency } \\
\eta[\%]\end{array}$ & 11.00 & 8.18 & 15.14 & 11.16 \\
\hline $\begin{array}{l}\text { Average irradiance } \\
\mathrm{E}\left[\mathrm{W} / \mathrm{m}^{2}\right]\end{array}$ & 1000 & 798.25 & 330.00 & 437.33 \\
\hline
\end{tabular}




\section{Summary}

The integration of the photovoltaics with the building allows for the replacement of the traditional materials used in the building industry with PV components. The prospect of adjustment of the BIPV to the building structure allowed for the use of the PV installation in buildings with unfavourable location or with complex or small roof covers. The use of the PV modules as an integral part of the building allows to generate savings resulting from the possession of an own source of electricity. The PV modules also fulfil other functions, as e.g.: they shade and cool rooms, constitute the thermal insulation, provide the protection against the atmospheric factors and constitute a uniform surface cover.

Analysis of the impact of shape and location of the flexible PV roof tile in relation to the source of radiation (conducted on one selected autumn warm and cloudless measurement day), has proven unambiguously that despite the easiness in the adaptation of the flexible roof tile to the building structure, the modules must not be integrated into all the planes and protuberances of the roof cover. The PV module which initially generated power at the level of $41.60 \mathrm{~W}$, after being set an angle of $\alpha=0^{\circ}$, produced about $25 \%$ less power despite a significantly lower intensity of the incident solar radiation. A change in the angles to $\alpha=90^{\circ}$ and $\beta=0^{\circ}$ resulted in the illumination of bypass diodes, which enabled the flow of current through the correctly operating module cells and the generation of power at the level of $30.87 \mathrm{~W}$. Significant differences in the radiation intensity on the respective roof tile sections are similar to the situation when the module operates in the area of local shading. In order to maximise the energy yield, it is necessary to ensure the maximum exposure of the roof tile to the sun; any part of the module surface which is bent or positioned in an improper manner in relation to the sun will cause a decrease in the power generation.

To sum up, the introduction of the building integrated photovoltaics into the building environment sheds new light on the ideas of energy efficiency. On top of this, the integration of the PV modules makes the BIPV components the only ecological energy generators, and creates an active, homogenous and waterproof system of the building structure. At present, such systems are independent, inter-disciplinary projects which integrate architecture with the photovoltaic industry.

\section{References}

1. A. Karaś, Czysta Energia 4 (2014)

2. A. Dobrzycki, D. Kurz, D. Laska, Poznan University of Technology Academic Journals. Electrical Engineering 87 (2016)

3. S. Pietruszko, VI Forum Operatorów Systemów $i$ Odbiorców Energii $i$ Paliw „Bezpieczeństwo energetyczne a nowe kierunki wytwarzania i wykorzystania energii w Warszawie”, (2009)

4. A. Bugała, K. Bednarek, L. Kasprzyk, A. Tomczewski, International Conference EEMS - Energy, Environment and Material Systems, (EEMS, E3S Web of Conferences 19,01002, 2017)

5. G. Frydrychowicz - Jastrzębska, A. Bugała, Energies \&, 1025 (2015)

6. D. Kurz, R. Nawrowski, International Conference EEMS - Energy, Environment and Material Systems, (EEMS, E3S Web of Conferences 19, 01039, 2017).

7. M. Goranova, B. Dimitrov, $18^{\text {th }}$ International Symposium on Electrical Apparatures and Technoligies (SIELA), (IEEEXplore, 14525500, 2014) 
8. E. Thomsen, J. Muric-Nesic, V. Everett, M. Brauers, E. Davies, T. Ratcliff, C. Samundsett, I. Skryabin, L. Xia, A. Blakers, 35th IEEE Photovoltaic Specialists Conference (PVSC), (11625533, 2010)

9. K. Nagarkar, $15^{\text {th }}$ IEEE Intersociety Conference on Thermal and Thermomechanical Phenomena in Electronic Systems (ITherm), (16159168, 2016)

10. J. Jajczyk, Computational Problems of Electr. Eng., 1-3 (IEEE Xplore, Sandomierz, 2016)

11. G. Trzmiel, Eksploatacja i Niezawodnosc - Maintenance and Reliability 19/4, 516 (2017)

12. P. Sharma, S. P. Duttagupta, V. Agarwal, International Conference on Sustainable Power Generation and Supply, (11001252,2009)

13. D. Burzyński, L. Kasprzyk, Energy and Fuels, (E3S Web of Conferences 14, 01041, 2017)

14. L. Kasprzyk, Eksploat Niezawodn 19/2, 229 (2017)

15. J. Jajczyk, A. Dobrzycki, M. Filipiak, D. Kurz, International Conference EEMS Energy, Environment and Material Systems, (EEMS, E3S Web of Conferences 19, 01027, 2017)

16. D. Głuchy, L. Kasprzyk, Prz Elektrotechniczny 93, 99 (2017)

17. https://www.ntechresearch.com/product/bipv-technologies-and-markets-2015-2022/, date: 23.02 .18

18. https://www.ntechresearch.com/product/bipv-technologies-and-markets-2017-2024/, date: 23.02 .18

19. M. Muszyńska-Łanowy, https://www.swiat-szkla.pl/kontakt/3424-bipv-fotowoltaikazintegrowana-z-budynkiem.html, date: 12.11.2017

20. G. Cipriani, V. Di Dio, R. Miceli, C. Spataro, G. Ricco Galluzzo, V. Rocca, L. Curcio, A. Parisi, A.C. Cino, R. Pernice, A. Ando, G. Adamo, A. Tomasino, S. Stivala, A.C. Busacca, G. Palmisano, D. La Cascia, 24 International Conference on Renewable Energy Research and Application (ICRERA), (14867700, 2014)

21. Ch. Konstantopoulos, E. Koutroulis, IEEE T Power Electr 29/6, 2817 (2014)

22. http://www.reconal.pl/fotowoltaika2/typy-ogniw-fotowoltaicznych, date: 26.11 .17

23. A. Zdyb, E. Krawczak, P. Lichograj, Opt Appl 2 (2016)

24. S. Gułkowski, E. Krawczak, International Conference EEMS - Energy, Environment and Material Systems, (EEMS, E3S Web of Conferences 19, 03006, 2017)

25. M. A. Green, Y. Hishikawa, E. D. Dunlop, D. H. Levi, J. Hohl-Ebinger, A. Ho-Baillie, Prog Photovoltaics 26/1, 3 (2018)

26. https://virtech.pl/fotowoltaika/oferta/panele-fotowoltaiczne/elastyczne/70wp-modulfotowoltaiczny-cigs-miasole-flex-01-70n, date: 25.11 .17 